\title{
Historical and contemporary biological diversity of Minnesota caddisflies: a case study of landscape-level species loss and trophic composition shift
}

\author{
David C. Houghton ${ }^{1}$ \\ Department of Biology, 33 East College Street, Hillsdale College, Hillsdale, Michigan 49242 USA
}

\author{
Ralph W. Holzenthal ${ }^{2}$ \\ Department of Entomology, 219 Hodson Hall, 1980 Folwell Ave., University of Minnesota, Saint Paul, \\ Minnesota 55108 USA
}

\begin{abstract}
The biological diversity reflected by nearly 300,000 caddisfly specimens collected throughout Minnesota since 1985 was compared with that of 25,000 specimens recorded prior to 1950 and was analyzed based on the 5 caddisfly regions of Minnesota. In the Lake Superior, Northern, and Southeastern regions, $>90 \%$ of species known historically from each region were recovered and additional species were discovered. In the Northwestern and Southern regions- the most disturbed areas of Minnesota-species recovery ranged from 60 to $70 \%$. Historical and contemporary assemblages were similar to each other in the former 3 regions and markedly different in the latter 2. Prior to 1950, species in all trophic functional groups were widespread in all regions. A similar pattern still exists in the Lake Superior, Northern, and Southeastern regions, whereas the Northwestern and Southern regions are now dominated by filtering collectors in all sizes of lakes and streams. Over 65\% of species extirpated from any region were in the long-lived families Limnephilidae and Phryganeidae, and 70\% of these same species were in the shredder functional group. Almost $30 \%$ of the statewide fauna has been found from $<5$ localities since 1950, suggesting a degree of imperilment on par with that of freshwater bivalves, gastropods, and fish. These observed losses of biodiversity and changes in trophic composition have probably occurred as a result of anthropogenic disturbance throughout most of the northcentral US.
\end{abstract}

Key words: Trichoptera, Minnesota, aquatic, biodiversity, caddisfly, extirpation, insect, conservation.

The biological diversity of aquatic insects-particularly that of endangered and threatened taxaremains poorly studied relative to that of vertebrates. The International Union for Conservation of Nature (IUCN) Red List of Threatened Species, for example, lists only 623 threatened insects, $0.07 \%$ of the total described insect fauna (IUCN 2009). In contrast, $20 \%$ (1098 species) of described mammals are considered threatened by the IUCN. Among the threatened insects, only 19\% (118 species) are freshwater species, and nearly $90 \%$ (106 species) of those are in the order Odonata (IUCN 2009). The IUCN only lists 4 species of threatened caddisfly, all of which are European species currently believed to be extinct. The US Fish and Wildlife Service has implemented Species Recovery Plans (SRPs) for only 3 endangered aquatic

\footnotetext{
${ }^{1}$ E-mail addresses: david.houghton@hillsdale.edu

2 holze001@umn.edu
}

insects, none of them caddisflies. In contrast, several hundred SRPs have been established for mammals, birds, and fish, including 28 for the bull trout (Salvelinus confluentus) alone (USFWS 2009).

Among the states of the north-central US (Illinois, Indiana, Iowa, Michigan, Minnesota, North Dakota, South Dakota, Wisconsin), $<5 \%$ of the respective caddisfly faunas are considered imperiled or extirpated (NatureServe 2009). In contrast, mammal listings for these same states range from 10 to $40 \%$. In Minnesota, only $0.7 \%$ (2 species) of the fauna is considered imperiled or extirpated, but $>95 \%$ of these species simply lack enough conservation data to assign them a rank (Fig. 1A). The Minnesota Department of Natural Resources (MNDNR 2009b) lists 13 species of caddisfly as Endangered or Special Concern in the state; 4 of these are either invalid species or are listed based on misidentified specimens (Houghton and Holzenthal 2003). 


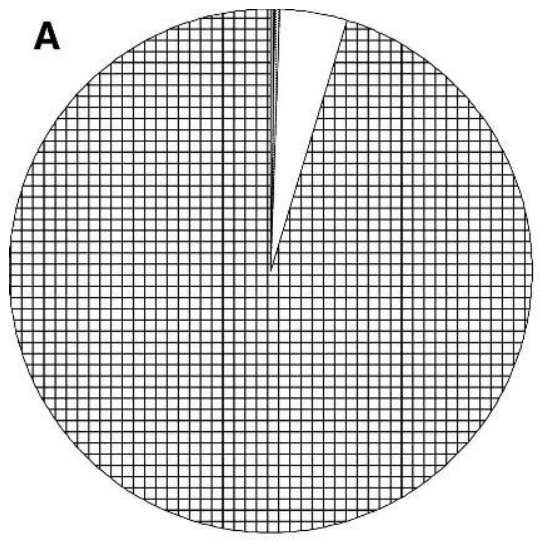

NatureServe (2009)

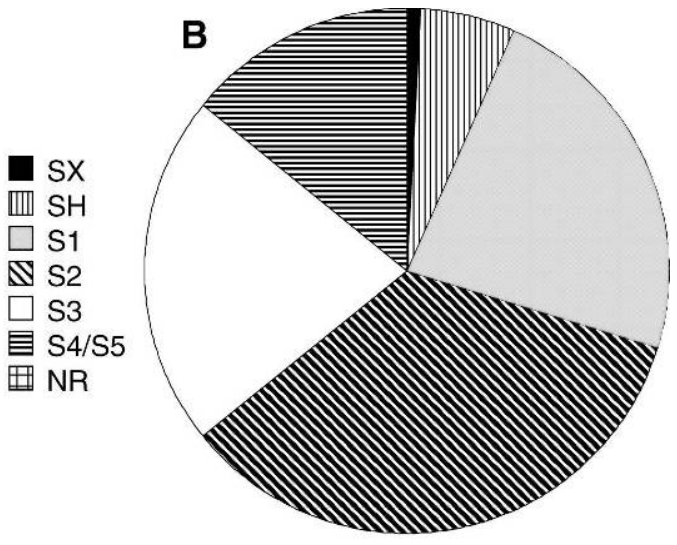

Current study

FIG. 1. The relative percentages of caddisfly species with conservation rankings of Apparently Secure (S4/S5), Vulnerable (S3), Imperiled (S2), Critically Imperiled (S1), Possibly Extirpated (SH), Presumed Extirpated (SX), or No ranking (NR) from NatureServe (2009) (A) and from our study (B).

This disparity in listing should not imply that insect biodiversity is not experiencing loss. It simply reflects a disproportionate level of study. Nationwide in the US, freshwater invertebrates have had $10 \%$ as much basic scientific research as freshwater fish-despite having approximately the same number of described species-and freshwater invertebrates on the Endangered Species List have had 1\% of the conservation research as listed vertebrates (Strayer 2006, USFWS 2009). Insects probably are experiencing a greater extinction rate than either birds or plants (Thomas et al. 2004, Thomas 2005). In terms of both habitat loss and pollution, freshwater ecosystems probably are far more imperiled than terrestrial ecosystems, and the rate of extinction within freshwater ecosystems appears to be 4 to $5 \times$ higher than that of terrestrial ecosystems (Ricciardi and Rasmussen 1999, Master et al. 2000). For example, $>60 \%$ of freshwater gastropods and $40 \%$ of freshwater mussels in the US are classified as extinct or imperiled on a national level (Lynse et al. 2008, Perez and Minton 2008). Wilcove and Master (2005) determined a $>30 \%$ imperilment level for all freshwater invertebrates for which conservation data have been compiled. Preliminary studies indicate a far greater extinction rate for aquatic insects than for terrestrial species (Thomas 2005). For example, DeWalt et al. (2005) found that $>50 \%$ of the stonefly fauna in Illinois was either extirpated or critically imperiled. They hypothesized that similar levels of endangerment were likely to be found for other aquatic insects in North America. This situation is especially serious considering the importance of aquatic insects in the normal functioning of freshwater lakes and streams (Allan 1995, Barbour et al. 1999).

To document a loss of biodiversity accurately, a comparison of contemporary biodiversity data with historical data is critical. Unfortunately, such historical data frequently do not exist for insects, particularly for largely inconspicuous insects, such as caddisflies. Basic statewide checklists and faunal studies of the order have been compiled for 43 US states and Canadian provinces (Wiggins 2008), but only 2 (Betten 1934, Ross 1944) were completed before 1950. Therefore, the more recent studies were done after much of the post-World War II habitat destruction that now dominates the landscape (e.g., Omernik 1987) had occurred, thus, decreasing their utility for assessing historical biodiversity loss. Furthermore, most checklists do not contain sufficient distribution data to make comparisons between historical and contemporary biodiversity patterns. In the absence of rigorous published data on historical caddisfly distributions, analysis of preserved specimens in museum collections must be used to evaluate changes in caddisfly biodiversity over time (Suarez and Tsutui 2004).

Minnesota is an ideal location in which to conduct studies on biodiversity loss. First, the state is situated at the intersection of the 3 largest biotic provinces in North America: Coniferous Forest, Deciduous Forest, and Prairie (Fig. 2). Thus, findings from the state might be representative of large areas of the northcentral US and south-central Canada. Second, large portions of Minnesota-in contrast to Illinois (DeWalt et al. 2005)—remain fairly undisturbed, so compar- 


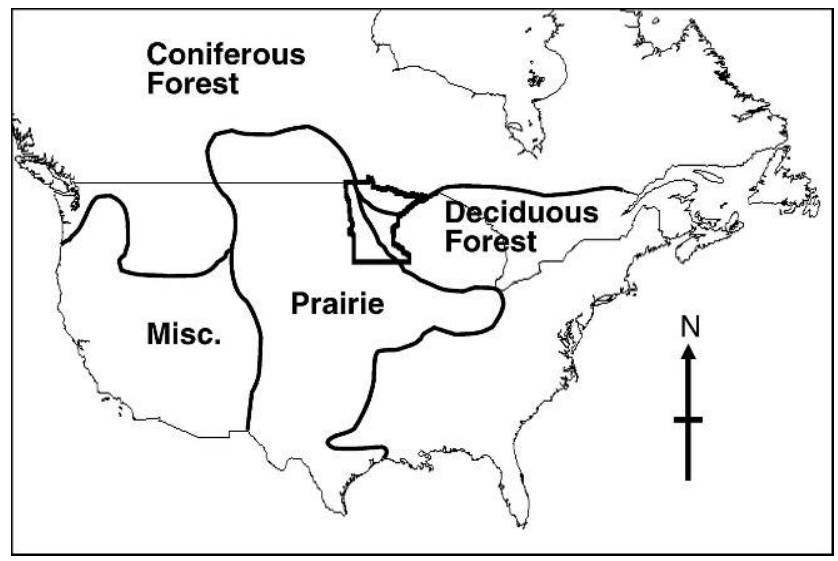

FIG. 2. The USA and southern Canada showing the convergence of the Coniferous Forest, Deciduous Forest, and Prairie biotic provinces within the state of Minnesota (Bailey 1980). Misc. = miscellaneous biotic provinces.

isons of variable species loss can be made within a fairly small area (Houghton 2004a). Third, the state has an amazing wealth of freshwater resources, including nearly 12,000 natural lakes $>4$ ha in size, $>100,000 \mathrm{~km}$ of streams and rivers, and nearly 4 million ha of wetlands (MNDNR 2009a). Last, caddisflies have been collected regularly in Minnesota since the 1890s, with the first statewide checklist compiled in 1936 (Elkins 1936). Nearly 25,000 specimens, most of them unpublished, have been collected from 1890 to 1950 and deposited in the University of Minnesota Insect Museum (UMSP).

In 2000 to 2001, Houghton (2004a) sampled the entire state representatively and collected $>200,000$ adult specimens. He used detrended correspondence analysis and a flexible unweighted pair-group method using arithmetic averages (UPGMA) algorithm to group 58 secondary watersheds into 5 caddisfly regions (Fig. 3A, B) based on relative abundance data. These regions had $\sim 2 \times$ the classification strength of any a priori classification based on ecological data or primary catchment (Houghton 2003) and, therefore, are the most appropriate units for sampling caddisflies within Minnesota (e.g., Hawkins et al. 2000). The Northwestern and Southern regions had markedly lower overall species richness relative to their size than did the other regions. Indeed, some single samples from the Northern region contained more species than all combined samples of the Northwestern region. Furthermore, ecosystems in the Northwestern and Southern regions of the state were dominated by fine-particle filtering collectors in all sizes of lakes and streams (Houghton 2007).

Houghton (2004a, 2007) hypothesized that the lower species richness and ecosystem homogenization observed in the Northwestern and Southern regions were caused, in large part, by the high level of habitat disturbance in these 2 regions (USGS 2002). However, in the absence of historical data, this hypothesis was tentative. Therefore, the objective of our study was to compare contemporary Minnesota caddisfly distribution data to that reflected by specimens stored in the UMSP before 1950 and to assess potential loss of biodiversity and changes in trophic functioning throughout the state. Because of Minnesota's location at the intersection of 3 biotic provinces,
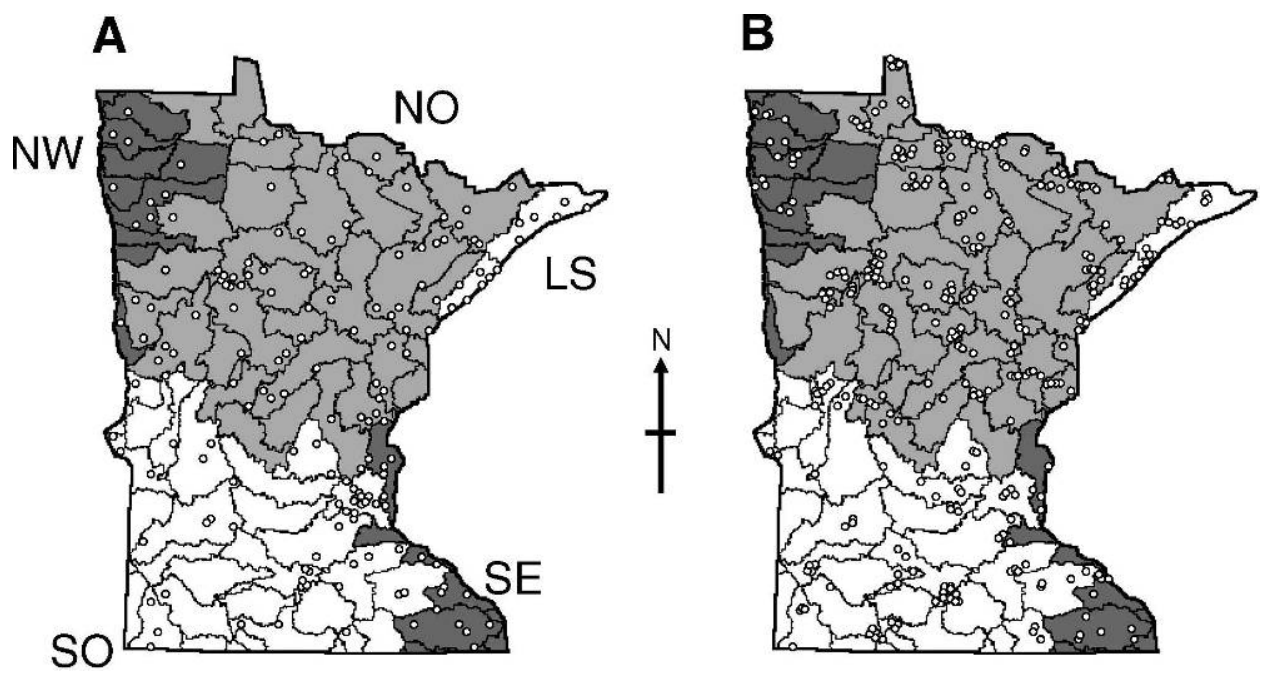

FIG. 3. Collecting localities for Minnesota caddisflies based on 5 predetermined caddisfly regions (Houghton 2004a) before 1950 (A) and after 1985 (B). Smaller regions are Minnesota watersheds. LS = Lake Superior, NO = Northern, NW = Northwestern, SE = Southeastern, SO = Southern. 
$100+y$ of collecting history, and varying levels of habitat disturbance, results probably will be applicable to many other areas in north-central US and south-central Canada.

\section{Materials and Methods}

A total of 24,167 specimens collected from the 1890 s through the 1940s and deposited into the UMSP were entered into the UMSP BIOTA database (Colwell 2007). These dates reflect the collecting of many workers, including W. Elkins, A. A. Granovsky, O. Lugger, and, especially, D. G. Denning. They also precede most habitat degradation in Minnesota (Omernik 1987, Tester 1995), and allow a 35-y window of time between historical and contemporary collections.

A total of 288,717 specimens collected since 1985the year that we began investigating the state faunaalso were entered in the BIOTA database. Collecting techniques included malaise trapping, sweep netting, aspirating from riparian rocks and vegetation, and suspending several 8-W ultraviolet lights in front of a white sheet for $\sim 2 \mathrm{~h}$ after dusk, with subsequent capture in a cyanide kill jar. From 2000 to 2001, we sampled representatively with light traps. For this technique, an 8-W portable ultraviolet light was set on top of a white enamel pan filled with $80 \%$ ethanol. Lights placed near aquatic habitats for $\sim 2 \mathrm{~h}$ after dusk attract most caddisfly species (Houghton 2004a). Traps were placed near $\geq 1$ small stream (width $<$ $4 \mathrm{~m}), \geq 1$ medium-sized stream $(4-15 \mathrm{~m}), \geq 1$ large river $(>15 \mathrm{~m})$, and $\geq 1$ lake or wetland for most of the 58 watersheds in Minnesota (Fig. 3B). Our objective was to collect adult caddisflies more representatively and with greater effort than they have been collected historically. All specimens analyzed in our study are deposited in the UMSP, and their locality data are accessible on the USMP website (http://www. entomology.umn.edu/museum/databases/).

A mean similarity dendrogram was calculated by an UPGMA algorithm using the program PC-ORD for Windows ${ }^{\circledR}$ (version 3.0; MjM Software Design, Gleneden Beach, Oregon). The dendrogram was computed on a 2-dimensional data matrix of species presence or absence by caddisfly region, both pre1950 and post-1985. UPGMA is a phenetic clustering method that calculates between-group similarities as the average of all possible pairs within each group (Oswood et al. 2000, McCune and Grace 2002). It produced a branching diagram of groups of caddisfly regions based on species composition with distances between groups expressed as \% similarity (e.g., Gauch 1982). The UPGMA algorithm in PC-ORD
TABLE 1. The number of caddisfly species collected historically, recently, and in sum total from 5 regions of Minnesota (Fig. 3A, B). Faunal recovery denotes the percentage of species known from a region historically and collected since 1985.

\begin{tabular}{lrrcc}
\hline \hline \multicolumn{1}{c}{ Region } & $\begin{array}{c}\text { Prior to } \\
1950\end{array}$ & $\begin{array}{c}\text { After } \\
1985\end{array}$ & $\begin{array}{c}\text { Total } \\
\text { number of } \\
\text { species }\end{array}$ & $\begin{array}{c}\text { Faunal } \\
\text { recovery } \\
(\%)\end{array}$ \\
\hline Lake Superior & 105 & 169 & 175 & 93.7 \\
Southeastern & 46 & 78 & 84 & 92.9 \\
Northern & 205 & 219 & 231 & 90.8 \\
Southern & 148 & 110 & 152 & 73.3 \\
Northwestern & 69 & 52 & 82 & 63.4 \\
\hline
\end{tabular}

automatically sets the base node of the tree to $0 \%$ similarity and the end nodes to $100 \%$. Longer branch lengths indicate a greater degree of dissimilarity and suggest that clusters at the end of such long branches constitute distinct groups (Oswood et al. 2000).

To construct species conservation rankings, we followed criteria adapted from NatureServe (2009): SX = Presumed Extirpated: species is believed to be extirpated from the state and not located despite intensive searches of historical sites and other appropriate habitat, and there is virtually no likelihood that it will be rediscovered; $\mathrm{SH}=$ Possibly Extirpated (Historical): species occurred historically in the state, and some possibility exists that it might be rediscovered, but its presence has not been verified in the past $30-40 \mathrm{y} ; \mathrm{S} 1=$ Critically Imperiled: critically imperiled in the state because of extreme rarity $(\leq 5$ occurrences); S2 = Imperiled: imperiled in the state because of rarity resulting from very few populations $(\leq 20) ;$ S3 = Vulnerable: vulnerable in the state because of relatively few populations $(\leq 80)$; S4/S5 = Apparently Secure: species might be uncommon, but engenders minimal cause for concern.

\section{Results}

A grand total of 278 caddisfly species have been documented from Minnesota (213 prior to 1950 and 253 after 1985). In the Lake Superior, Northern, and Southeastern caddisfly regions, we collected more species after 1985 than had been collected historically (Table 1). Faunal recovery-the percentage of species known from a region historically and collected since 1985-ranged from $\sim 91 \%$ to $\sim 94 \%$. Conversely, faunal recovery was $\sim 73 \%$ in the Southern region and $\sim 63 \%$ in the Northwestern region, and we found fewer species than had been collected historically (Table 1). Species known from a region but not collected since 1985 were confined to 8 families, with 
TABle 2. Percentage of regional extirpations of 8 caddisfly families relative to the family's percentage of the statewide fauna, based on all known Minnesota species. No other family contained regionally extirpated species.

\begin{tabular}{lccc}
\hline \hline \multicolumn{1}{c}{ Family } & $\begin{array}{c}\text { \% of } \\
\text { statewide } \\
\text { fauna }\end{array}$ & $\begin{array}{c}\text { \% of } \\
\text { regionally } \\
\text { unrecovered } \\
\text { species }\end{array}$ & $\begin{array}{c}\text { Unrecovered } \\
\text { species/ } \\
\text { statewide } \\
\text { fauna }\end{array}$ \\
\hline Arctopsychidae & 0.3 & 1.1 & 4.1 \\
Brachycentridae & 2.1 & 1.1 & 0.5 \\
Hydropsychidae & 12.0 & 4.9 & 0.4 \\
Hydroptilidae & 21.1 & 6.1 & 0.3 \\
Leptoceridae & 17.6 & 11.9 & 0.7 \\
Limnephilidae & 18.0 & 44.2 & 2.5 \\
Phryganeidae & 5.6 & 21.2 & 3.8 \\
Polycentropodidae & 8.8 & 9.6 & 1.1 \\
\hline
\end{tabular}

the Arctopsychidae, Limnephilidae, and Phryganeidae experiencing species loss at a level greater than their relative proportion of the statewide fauna (Table 2).

Based on the UPGMA analysis, pre-1950 and post1985 caddisfly assemblages appear to be similar to each other in the Lake Superior, Northern, and Southeastern regions (Fig. 4), results suggesting no substantive changes to these faunas on a regional level during the last several decades. Conversely, the pre-1950 assemblage in the Northwestern region was most similar to that of the Northern region, whereas the post-1985 assemblage was most similar to the post-1985 assemblage of the Southern region. The pre1950 assemblage of the Southern region appeared unique, with some similarity to those of the Northern, Northwestern, and Lake Superior regions (Fig. 4).

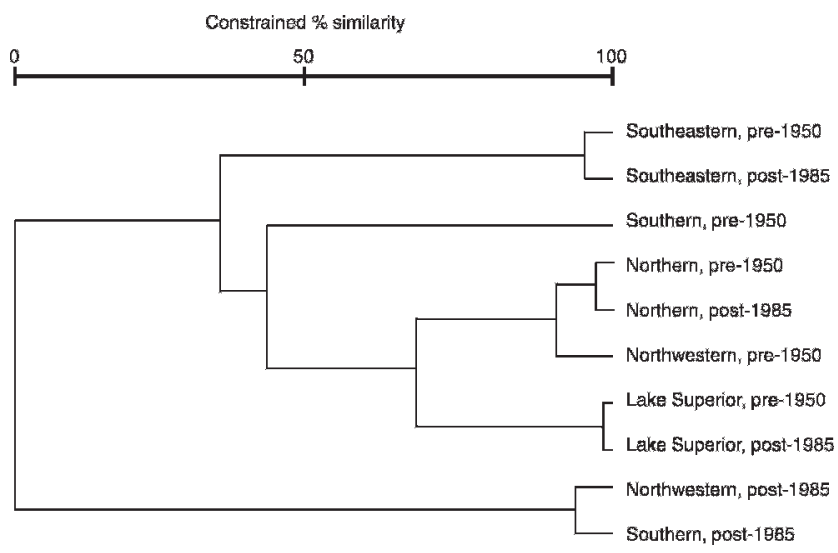

FIG. 4. Flexible unweighted pair-group method using arithmetic averages (UPGMA) dendrogram of 5 predetermined caddisfly regions based on presence or absence data for the 278 Minnesota caddisfly species. Terminal branches were set to $0 \%$ and $100 \%$ similarity.
TABle 3. Percentage of regional extirpations of 5 caddisfly trophic functional groups relative to the group's percentage of all known Minnesota statewide fauna.

\begin{tabular}{lccc}
\hline \hline $\begin{array}{c}\text { Trophic } \\
\text { functional } \\
\text { group }\end{array}$ & $\begin{array}{c}\text { \% of } \\
\text { statewide } \\
\text { fauna }\end{array}$ & $\begin{array}{c}\text { \% of } \\
\text { regionally } \\
\text { unrecovered } \\
\text { species }\end{array}$ & $\begin{array}{c}\text { Unrecovered } \\
\text { species/ } \\
\text { statewide } \\
\text { fauna }\end{array}$ \\
\hline $\begin{array}{l}\text { Filtering } \\
\text { collectors }\end{array}$ & 18.1 & 6.5 & 0.36 \\
$\begin{array}{l}\text { Gathering } \\
\quad \text { collectors }\end{array}$ & 30.6 & 9.8 & 0.32 \\
$\begin{array}{l}\text { Predators } \\
\begin{array}{l}\text { Scrapers } \\
\text { Shredders }\end{array}\end{array}$ & 12.1 & 10.9 & 0.90 \\
\hline
\end{tabular}

Only 2 species appear extirpated from the entire state (see below). Many species, however, were not recovered from particular regions where they had been collected previously. Such species are assumed to be extirpated from these regions. The families Limnephilidae (44.2\%) and Phryganeidae (21.2\%) represented $>65 \%$ of regionally extirpated species, despite collectively representing $<24 \%$ of the statewide fauna (Table 2). Species in all other families appear to be regionally extirpated relative to their proportion of the fauna. Regional extirpations also were common in the shredder functional group, which included nearly $72 \%$ of unrecovered species despite containing $<30 \%$ of the fauna (Table 3 ). Species in other functional groups were recovered relative to their percentage of the statewide fauna. These trends in familial and functional group extirpations were similar across all caddisfly regions (Figs 5, 6).

Prior to 1950, the 10 most widespread species within each region represented a diversity of families and trophic functional groups within all regions (Table 4). The 10 most widespread species collected since 1985 were similar to those collected historically in the Lake Superior (6 of 10), Northern (6 of 10), and Southeastern (7 of 10) regions (Table 4). Likewise, a diversity of trophic functional groups was represented. In contrast, $<1 / 2$ of the 10 most widespread species collected since 1985 were similar to historically widespread species in the Northwestern (3 of 10) and Southern ( 3 of 10) regions, and both regions are now dominated by filtering collectors -7 of 10 in the Northwestern and 6 of 10 in the Southern regions (Table 4).

Two species that appeared widespread throughout the Northwestern region prior to 1950, Agrypnia glacialis (Phryganeidae) (Fig. 7A) and Anabolia sordida (Limnephilidae) (Fig. 7B) appear extirpated from 


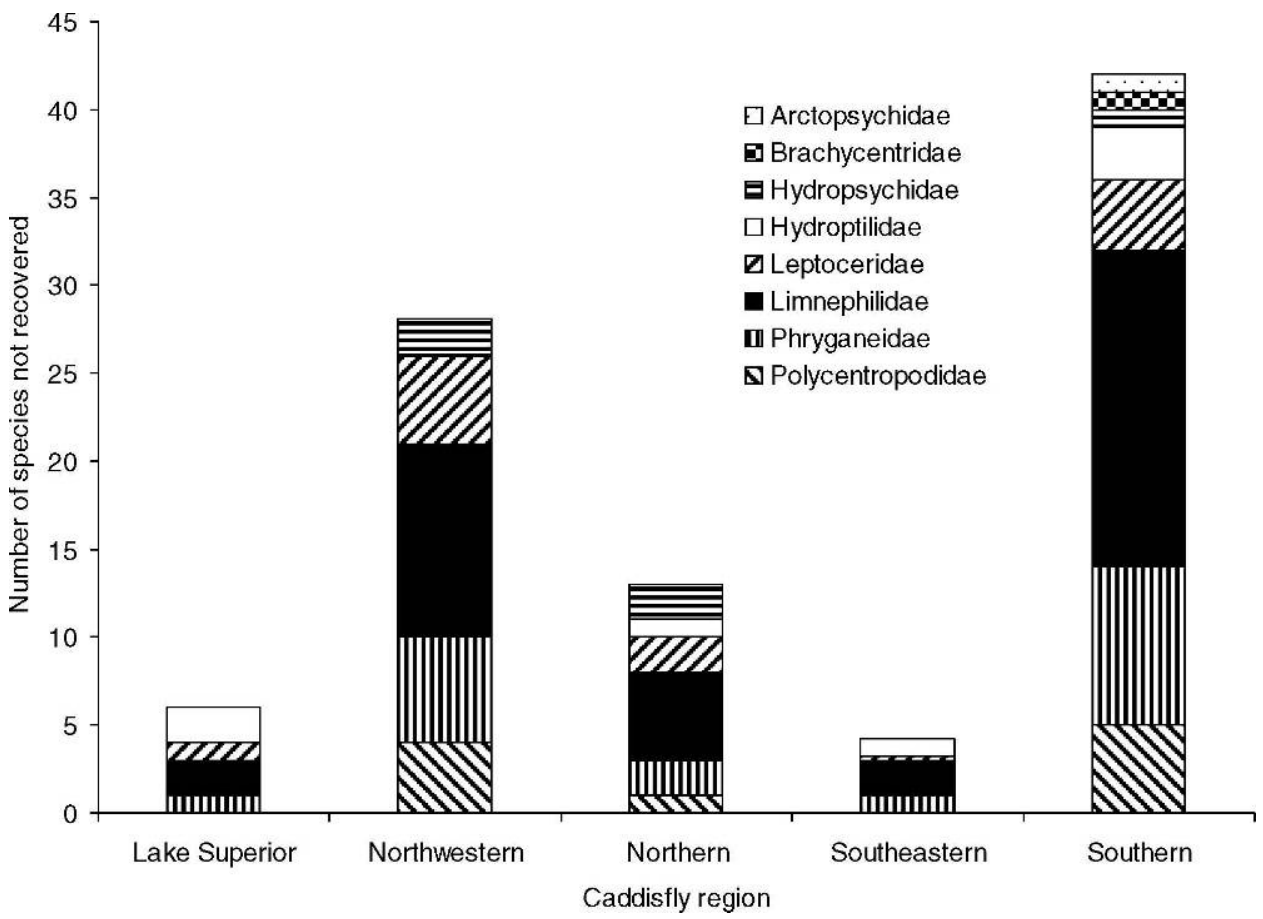

FIG. 5. The number of caddisfly species within 8 families known historically from each of the 5 caddisfly regions and not collected after 1985 (Fig. 3A, B).

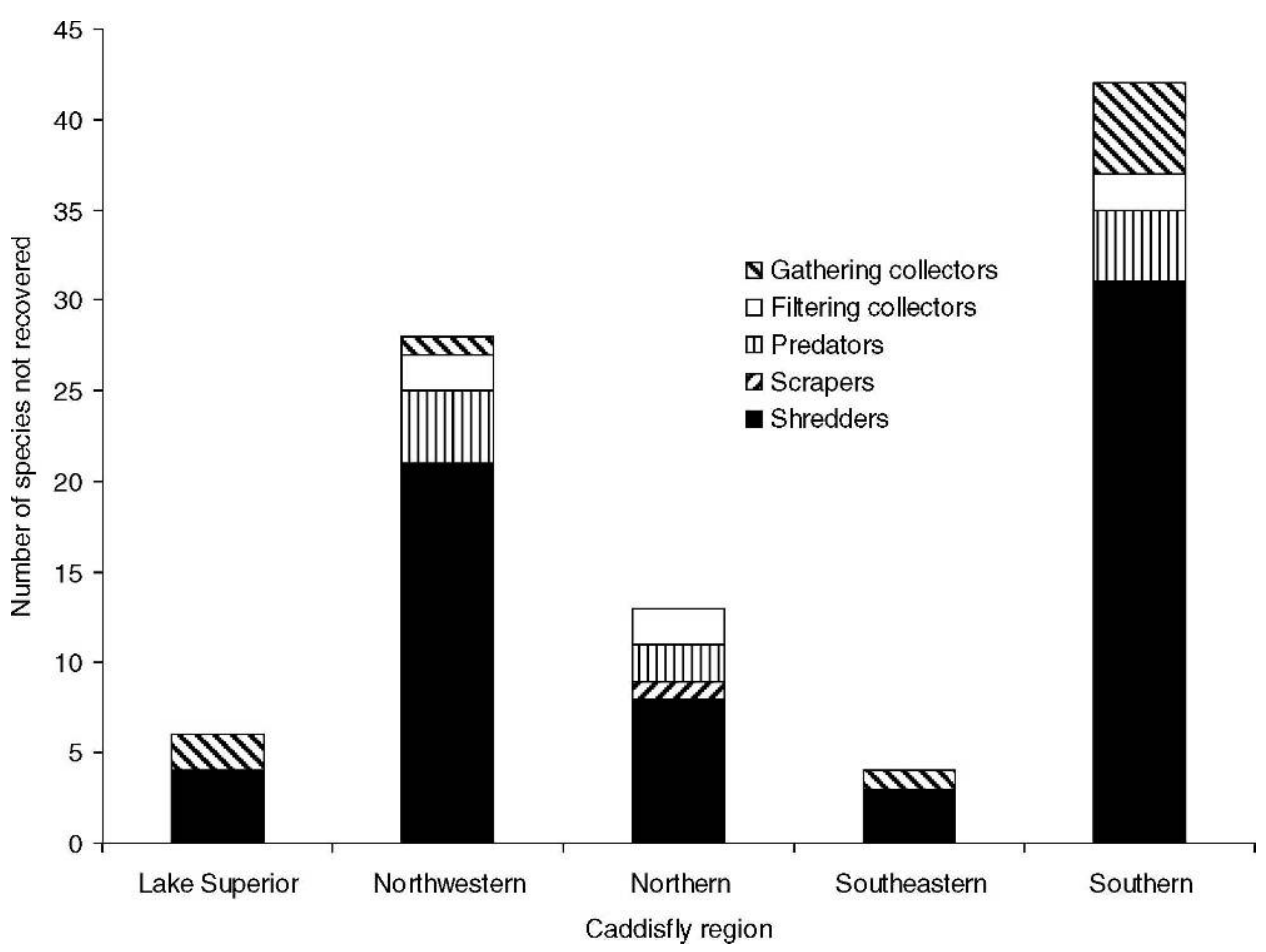

FIG. 6. The number of caddisfly species within 5 trophic functional groups known historically from each of 5 caddisfly regions and not collected after 1985 (Fig. 3A, B). 


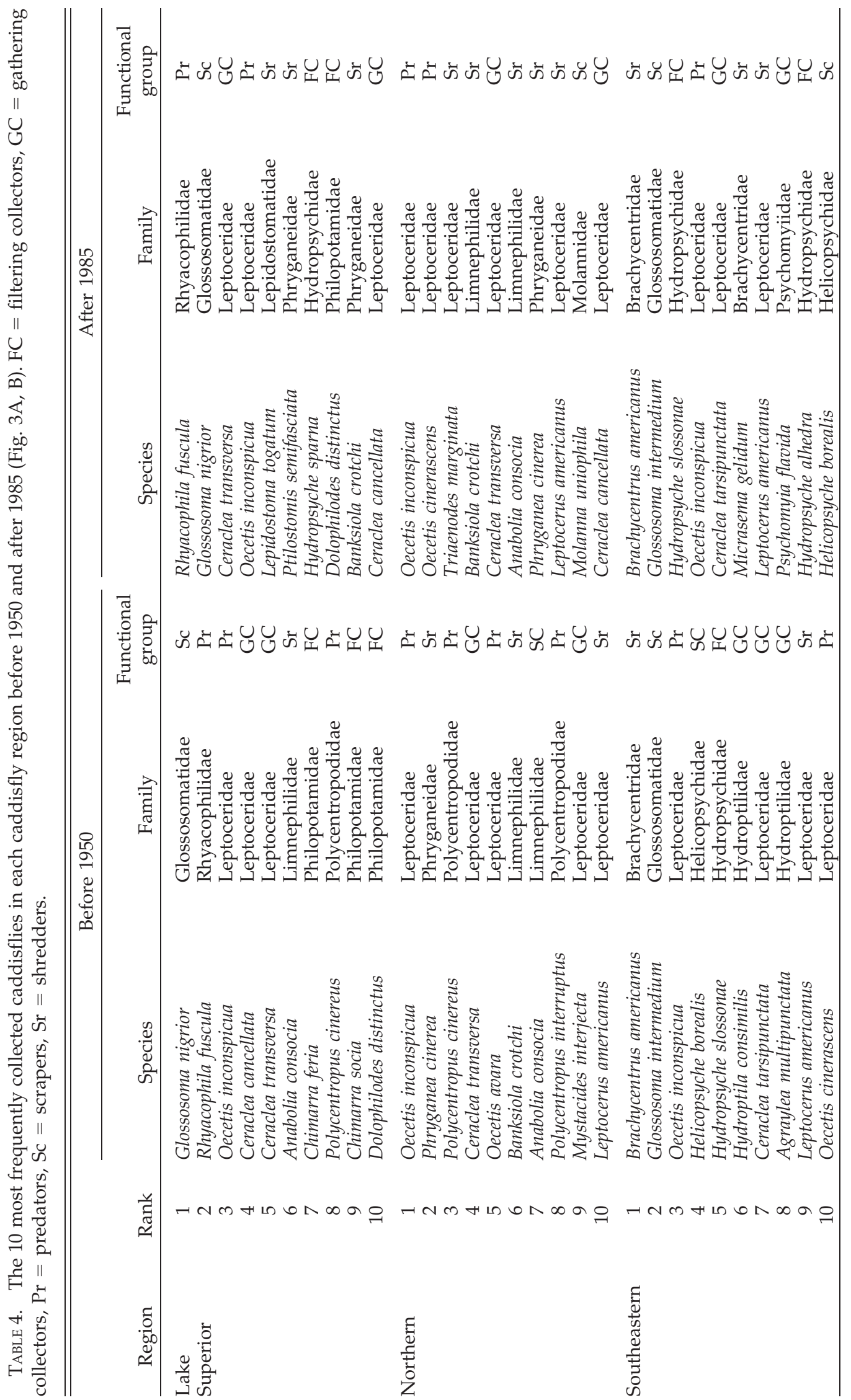

This content downloaded from 134.084.028.154 on June 21, 2017 07:43:14 AM 


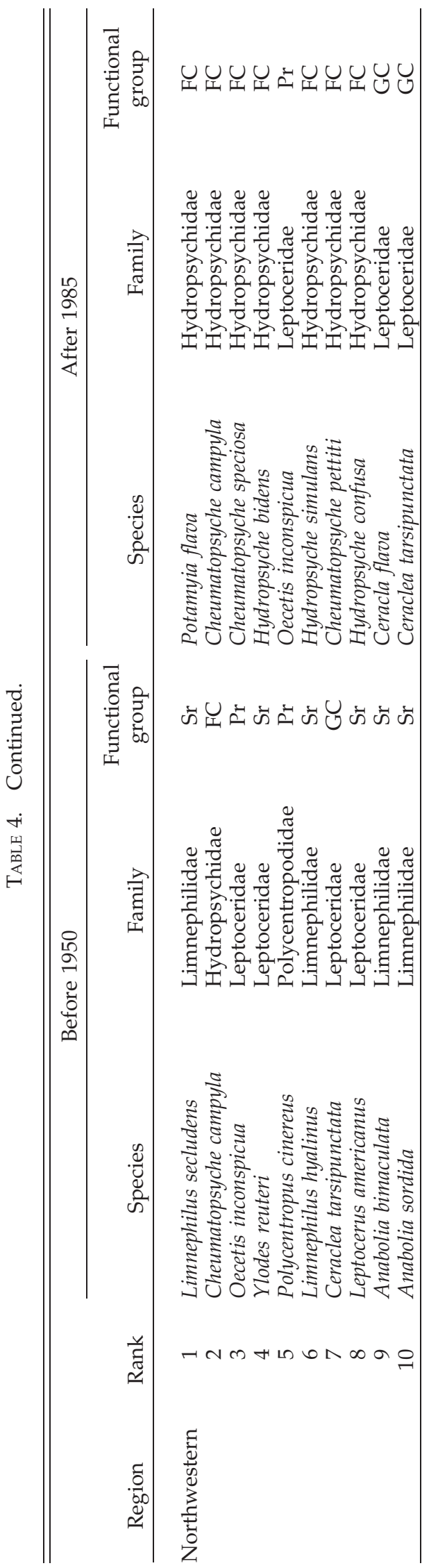

Minnesota; the latter species was the $10^{\text {th }}$-most widespread species in the Northwestern region before 1950. Another species, Limnephilus secludens (Limnephilidae), the single most widespread species of the Northwestern region before 1950 (Table 4) and found sporadically elsewhere in the state, is known since 1985 from only a single specimen (Fig. 7C). Conversely, Potamyia flava (Hydropsychidae), which was collected infrequently in the state before 1950 is now widely distributed in the Northwestern and Southern regions and is found occasionally in the Northern and Southeastern regions (Fig. 7D). Almost 30\% (82 species) of the entire fauna has been found from $<5$ locations since 1985, and $>60 \%$ (179 species) has been found from $<20$ locations. Similarly, $>25 \%$ (81 species) of species are known from $<10$ specimens (Fig. 8). Based on our data, we have assigned tentative conservation rankings to the fauna (Fig. 1B).

\section{Discussion}

A substantial component of Minnesota caddisfly biodiversity appears to have been lost from at least the Northwestern and Southern regions of the state, and probably from portions of the other regions as well. Most historical collections contain $<5$ total specimens each, suggesting rather haphazard collecting. Indeed, many of D. G. Denning's collections came from night lights at gas stations in the middle of small towns. In contrast, our sampling strategy was far more rigorous, used many more techniques, and collected $>10 \times$ as many specimens. We expected to collect nearly all of the species found historically and to collect additional species not previously discovered. That we were unable to meet this expectation in the Northwestern and Southern regions-while meeting it in the other regions-strongly suggests many regional extirpations.

\section{Regional extirpations: taxonomic and functional groups}

The observed loss of regional species richness was especially noticeable among the large, long-lived shredders of the Limnephilidae and Phryganeidae. These 2 families had 3 of the 10 most widespread species of the Northwestern region and 2 of the most widespread in the Southern region prior to 1950. Now, neither family has a representative in the top 10 most widespread species of either region. Statewide, species of Limnephilidae have been regionally extirpated at $>2 \times$ the family's proportion of the statewide fauna. Regional extirpations in the Phryganeidae are even more profound-nearly $4 \times$ its proportion of the statewide fauna. The family Arctopsychidae (subfamily Arctopsychinae of Hydro- 
[Volume 29
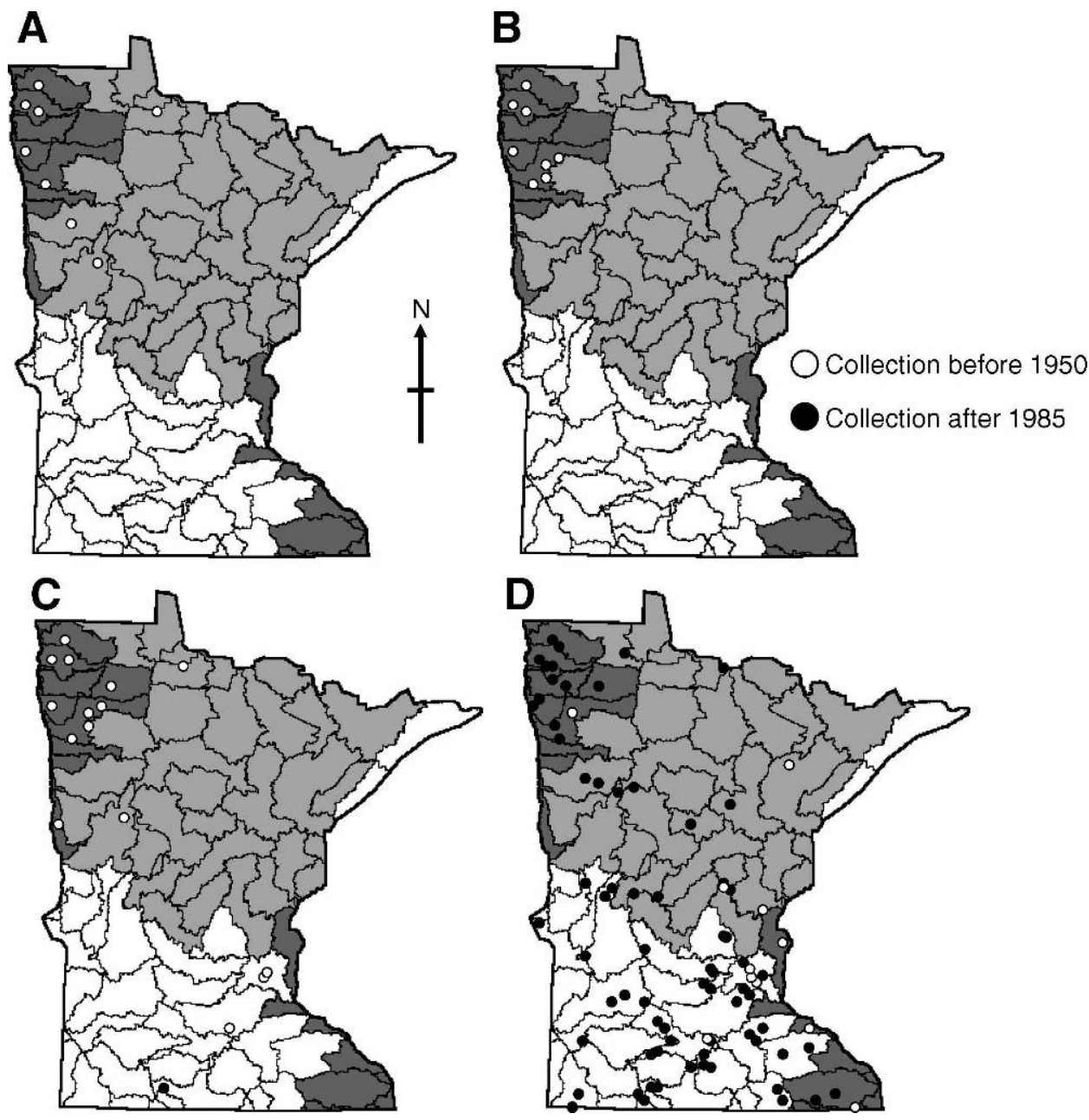

Fig. 7. The historical and contemporary distributions of 4 Minnesota caddisfly species, Agrypnia glacialis (A), Anabolia sordida (B), Limnephilus secludens (C), and Potamyia flava (D).

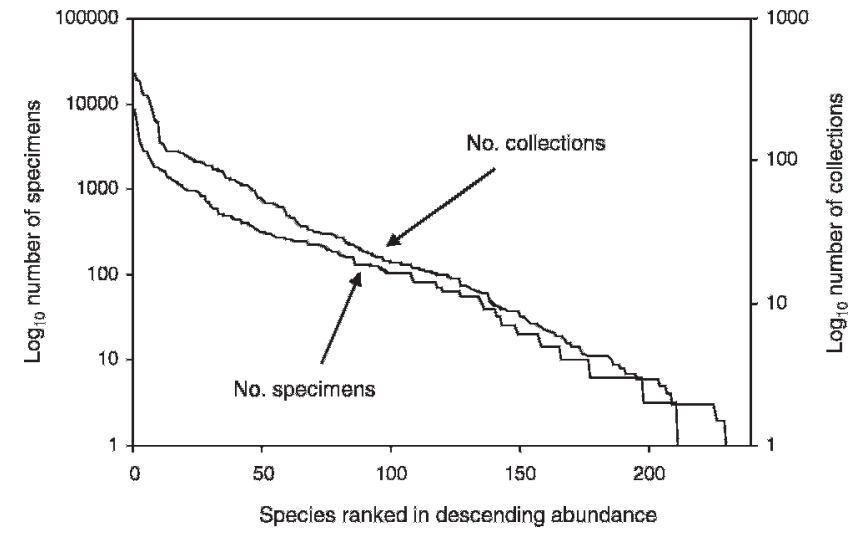

FIG. 8. The number of caddisfly specimens known for each Minnesota species, and the number of collections in which each species has been found. psychidae in some classifications) has a similar ratio of regional extirpations relative to the statewide fauna; however, determining the significance of this result is difficult because only a single species is known from the state, and only a single regional extirpation has occurred.

Limnephilids and phryganeids might be susceptible to extirpation because of their long lifespan and their feeding habits. All species in these 2 families appear to be uni- or semivoltine (Wiggins 2008). This long larval stage exposes them to habitat disturbances for a longer period than a multivoltine species would experience. DeWalt et al. (2005) found that large, longlived stoneflies had a similar vulnerability to extirpation in disturbed regions of Illinois. The biodiversity loss is similarly profound in species of the shredder functional group. Shredder species appear regionally extirpated at $>2 \times$ the proportion of the statewide fauna. Shredders are especially vulnerable to changes 
in riparian habitat-especially a loss of canopy cover and an increase in sedimentation-because they depend on coarse allochthonous debris for their food source (Barbour et al. 1999, Wiggins 2008). Before 1950, 6 and 4 of the 10 most widespread species in the Northwestern and Southern regions, respectively, were shredders. Now no species in the top 10 of either region is a shredder. Many limnephilids and phryganeids are shredders (e.g., Wiggins 2008), a concurrence suggesting that both their feeding habits and their long lifespan are contributing to their decline.

Conversely, species in the Hydropsychidae, particularly Potamyia flava, appear far more widespread in Minnesota now than they were historically. Currently this family has $60 \%$ and $70 \%$ of the most widespread species of Southern and Northwestern regions, respectively. Hydropsychids are all within the filtering-collector trophic functional group, and they tend to be tolerant of habitat disturbance (Barbour et al. 1999). Some species even increase in streams polluted by agriculture because they use fine $(<0.25 \mathrm{~mm})$ particulate organic matter input as a food resource (Barbour et al. 1999, Houghton 2007, Wiggins 2008). Therefore, agricultural disturbance might promote an increase in the abundance of some filtering collector species while decreasing overall species richness (Allan 1995, Roth et al. 1996, Barbour et al. 1999), phenomena that appear to be occurring in at least the Northwestern and Southern regions. Houghton (2004b) found that the presence of 3 hydropsychids, Cheumatopsyche campyla, Hydropsyche simulans, and Potamyia flava, was a strong indicator of habitat disturbance throughout Minnesota, particularly in small to medium streams. All 3 of these species typically are abundant in large rivers, a result suggesting that the presence of agricultural input into smaller streams is giving such streams the characteristics of larger rivers. In particular, Potamyia flava appears to have increased markedly in incidence throughout the state since 1950, especially in the Northwestern and Southern regions.

\section{Prairies, forests, and disturbance}

In the absence of historical data, the observed low species richness, high incidence of filtering collectors, and low incidence of shredders in the Northwestern and Southern regions could have been attributed to the predominance of the Prairie biotic province within these regions (Houghton 2004a). Prairie aquatic ecosystems in Minnesota tend to be low gradient, flood-prone, and with relatively little heterogeneity in substrate or stream flow relative to those of the
Coniferous and Deciduous Forest biotic provinces, which predominate in the other regions (Matthews 1988, Tester 1995). Several authors (Statzner and Higler 1985, Wiley et al. 1990, Dodds et al. 1996, Gray 1997) have suggested that streams in natural prairie ecosystems do not fit into the normal stream models, but instead exhibit increasing relative canopy cover into the middle stream reaches. Erosion of nutrientrich prairie soil might lead to naturally high levels of dissolved N and P in prairie streams (Buol et al. 1989, Anderson et al. 2001). The combination of limited canopy cover and high nutrient availability could promote ecosystem autotrophy, a lower-than-expected abundance of shredders, and a higher-thanexpected abundance of filtering collectors.

However, a comparison of contemporary data with historical data suggests that, despite the abundance of prairie habitats in the Northwestern and Southern regions, the observed low species richness, low abundance of shredders, and high abundance of filtering collectors is recent and predominantly the result of anthropogenic disturbance, not natural factors. Before 1950, the Northwestern and Southern regions had disparate caddisfly faunas. The Northwestern region was most similar to the Northern region, and the Southern region formed its own unique branch. Now Northwestern and Southern regions have faunas most similar to each other. This contemporary similarity probably is the result of an overall low species richness within the 2 regions, which was caused by ecosystem homogenization (Houghton 2007).

The most likely cause of the observed homogenization in the Northwestern and Southern regions is agriculture. Intensive agriculture probably has the most extensive impact of any human land use on aquatic ecosystems (Allan 1995, Wang et al. 1997, Sponseller et al. 2001, Williams et al. 2003, Zimmerman et al. 2003, Allan 2004). Agriculture often leads to stream channelization, draining of wetlands, modification or loss of the surrounding floodplain, and removal of riparian canopy cover with subsequent loss of coarse allochthonous input (Gregory et al. 1991, Allan 1995, Delong and Brusven 1998, Quinn 2000, Brinson and Málvarez 2002). Agricultural runoff into aquatic habitats often contains large amounts of sediment and fine organic matter (Turner and Rabalais 1991, Zweig and Rabeni 2001). Collectively, these impacts promote homogenization of stream microhabitats and an increase in secondary production, especially in small to medium streams. Essentially, small streams develop the characteristics of large rivers (Delong and Brusven 1992, 1993, Pringle et al. 1993, Houghton 2007). Riparian disturbance with 
subsequent nutrient and sediment input was found to be the most widespread stressor of streams throughout the US (Paulsen at al. 2008). The Northwestern and Southern regions are dominated by agricultural land use, whereas much of the Northern, Lake Superior, and portions of the Southeastern region are forested (USGS 2002).

It is unlikely that the caddisfly faunas of the Lake Superior, Northern, and Southeastern regions are completely natural. Many of the watersheds throughout Minnesota that are now forested were previously logged or cultivated, with resulting loss of woody debris and sediment, and floodplain and channel modification, effects that can last for tens or hundreds of years (Naiman et al. 1988, Perkins 1994, Bierley et al. 1999, Johnson et al. 2003, Allan 2004). How much effect historical disturbance has on contemporary biological diversity is not clear. In a study of Appalachian forests, Harding et al. (1998) found that the fauna of former agricultural landscapes was more similar to that of current agricultural landscapes than it was to that of primary forest. Wang et al. (2001) attributed differences in fish diversity along an urbanization gradient to the effects of prior agriculture along the stream. Conversely, Wang et al. (2003) found that anthropogenic disturbance was less important than natural features in predicting fish assemblages in the relatively undisturbed ecosystems of northern Michigan and Wisconsin, a landscape similar to that of northern Minnesota. Allan (2004) suggested that when human disturbance is "minor," biological diversity is more affected by natural factors than by land use. It is difficult to address changes in caddisfly diversity within a region because of the limitations of the historical data (see below), but the Lake Superior, Northern, and Southeastern regions of Minnesota appear in obvious contrast to the Northwestern and Southern regions.

\section{Statewide extirpations}

Nineteen caddisfly species have not been collected in Minnesota since 1950. Seventeen of these species (e.g., Philarctus quaeris, Banksiola smithi) are known from $<10$ specimens in historical collections. Thus, it is difficult to know whether their absence now reflects extirpation, natural rarity, or difficulty of collection. Therefore, we have ranked these species as $\mathrm{SH}$ (possibly extirpated; Fig. 1B). In contrast, 2 historically common species, Anabolia sordida (Limnephilidae) and Agrypnia glacialis (Phryganeidae), do appear extirpated (SX) from Minnesota. Both were common throughout the Northwestern region through the 1940s but have not been collected since. These species are large and readily attracted to lights, so it is unlikely that they have been overlooked. Another species, Limnephilus secludens (Limnephilidae), was commonly collected throughout the Northwestern and Southern caddisfly regions, but has been found recently only from a single site. Historically, $L$. secludens was known predominantly from very small streams. Its only recent Minnesota collection was near a stream of width $<0.5 \mathrm{~m}$. Such habitats are now extremely rare in the Northwestern and Southern regions of Minnesota (e.g., Houghton 2004a).

\section{Regional implications}

If the patterns found in our study hold true throughout the north-central portion of the US, then it is likely that a large amount of regional caddisfly biological diversity has already been lost. NatureServe (2009) considers any species known from $<5$ locations within a state to be Critically Imperiled and any from $<20$ to be Imperiled. By these definitions, almost $30 \%$ of the Minnesota caddisfly fauna is critically imperiled and $>60 \%$ is imperiled, an increase of nearly 2 orders of magnitude over the official NatureServe ranking (Fig. 1A). The increase in the number of caddisfly species at risk in Minnesota clearly reflects a lack of rigorous conservation research before our study because the vast majority of Minnesota species have no previous ranking. A similar situation exists in other states of the northcentral US, where $>90 \%$ of species cannot be ranked because of insufficient conservation data.

Overextrapolating our results is a possible danger, but we suspect that caddisfly faunas are in worse condition in other north-central states than in Minnesota. Minnesota has far more refuge habitats, especially in the Northern and Lake Superior Regions, than do most other north-central states. Indeed, $>80 \%$ of the original Coniferous Forest and $\sim 60 \%$ of the Deciduous Forest in Minnesota remain standing, albeit fragmented in places and subjected to historical logging (USGS 2002). Conversely, $>95 \%$ of Minnesota's prairie has been converted to agriculture or urban environments. This latter situation is found in most other north-central states. For example, Iowa, Illinois, and Indiana are some of the most disturbed states in the country, with large-scale agriculture and urbanization accounting for $80-90 \%$ of the land use and with few refuge habitats remaining (USGS 2002). More generally, $>70 \%$ of the wadeable streams of the Plains and Lowlands region of the US-which includes the states mentioned in our study as well as others-are in Fair or Poor condition (Paulson et al. 2008). 
If our results can be extrapolated to areas of the north-central US with similar land use, then the level of caddisfly imperilment is probably at least as high as that of crayfish, mussels, gastropods, or fish on the national level (Master et al. 2000, Lynse et al. 2008, Perez and Minton 2008). Other aquatic insects, especially those normally classified as intolerant, such as stoneflies and mayflies, probably have experienced similar losses of biodiversity. This hypothesis is supported by DeWalt et al.'s (2005) finding of $>50 \%$ extirpation or imperilment of stoneflies in Illinois.

The ecosystem homogenization and shift in trophic functional composition seen in areas of Minnesota dominated by large-scale agriculture probably are occurring in a large portion of the north-central US. Large-scale agriculture covers $>90 \%$ of the Prairie biotic province, $95 \%$ of the Minnesota River basin, and nearly $70 \%$ of the upper Mississippi River basin (Tester 1995, Allan 2004, Benke and Cushing 2004). A large amount of biological diversity probably already has been lost as diverse ecosystems became homogenized into ecosystems dominated by pollutiontolerant filtering collectors.

\section{Limitations of historical data}

Collections of caddisfly specimens before 1950 appear to have been done in a haphazard manner. Thus, any possible collector bias from this era is difficult to ascertain. Such a bias, if it existed, could have influenced our results. For example, both the Limnephilidae and Phryganeidae contain large, conspicuous, and strong-flying adults that are readily attracted to lights (Houghton 2004a). Thus, they could have been overrepresented in historical collections relative to their actual abundance. If so, then the magnitude of their decline might be overstated in our paper. Conversely, our observed increase in hydropsychids, such as Potamyia flava, also might be overstated because collector disinterest could cause such species to be underrepresented in historical collections. However, we mitigated such potential concerns by analyzing species incidence rather than species abundance. Furthermore, we evaluated extirpations on a regional level, rather than in smaller areas, such as watersheds. Thus, a single collection of a species and multiple collections of a species were both recorded as species presence within a region, regardless of the abundance of that species. Therefore, over- and underrepresentation of species because of collector bias probably had minimal effect on our analyses.

Indeed, because of our concerns about possible historical collecting bias and our subsequent conser- vative approach to analysis, we are not convinced that caddisfly biodiversity has remained stable since 1950 even in the Lake Superior, Northern, and Southeastern regions, despite our stated conclusions. In our study, a single collection from a region counted as a species recovery even if the distribution of that species had been reduced elsewhere in the region. For example, species recovery was $>90 \%$ in the Southeastern region despite large-scale disturbance throughout the region. This recovery rate was almost entirely because of the state park system that protects the forested headwaters of many small and medium streams (USGS 2002). Other areas of the region now contain very little caddisfly diversity and, thus, we suspect that many species have been locally extirpated. However, rigorously assessing such potential changes in subregional distributions is impractical because of the limitations of the historical data. With good baseline data now in place for Minnesota and available online, any future changes to the fauna can be evaluated with greater confidence and precision.

\section{Taxonomy, museums, and conservation}

Any scientific species recovery plan must begin with a well-established taxonomy (Wheeler 2004). For example, terrestrial birds and mammals are almost certainly listed as Threatened (IUCN 2009) more frequently than are insects simply because they are conspicuous, well known, and easier to identify. In the case of birds, scientific contributions from amateurs with field guides are as important as those from professionals (e.g., LeBaron 2008). In contrast, insects are difficult to identify to the species level without substantial training, and the number of such trained taxonomists is in decline (Moulton 2004). Furthermore, many bird and mammal faunas have been studied for $>100 \mathrm{y}$-often without substantial changes to their taxonomy-yielding many published historical data to compare with contemporary data. In contrast, insect systematics is far more dynamic, rendering nearly all published data obsolete except to the diminishing number of taxonomic experts. Indeed, both the NatureServe and Minnesota Department of Natural Resources lists of at-risk Minnesota caddisflies contain many taxonomic errors, including misidentified specimens, synonymized species, and nomina dubia (Houghton and Holzenthal 2003).

In the absence of a well-established taxonomy or ample historical published data and with the biological integrity of freshwater ecosystems continuing to decline (Karr and Chu 1999, Paulsen at al. 2008, Shapiro et al. 2008), the aquatic insect conservation biologist faces a serious challenge. In fact, some 
authors (e.g., Wishart and Davies 2003, Strayer 2006) have argued that traditional species-based conservation is impractical for aquatic invertebrates because of the lack of conservation data, the high degree of imperilment of the faunas, and the need to protect large drainage basins instead of merely the local habitats where aquatic invertebrates occur. However, before the protection of such large habitats can be justified realistically to a skeptical public, conservationists must first clearly demonstrate that declines in aquatic insect biological diversity have occurred. Ultimately, museums remain the single best source of historical data for assessing changes in biological diversity, especially as is the case of the UMSP, when such data are in a database and available to the scientific community (Krishtalka and Humphrey 2000, Guralnick and Van Cleve 2005, Flemons et al. 2007). Unfortunately, support for such collections is decreasing worldwide (Graham et al. 2004, Suarez and Tsutui 2004, Winkler 2004, Gaubert et al. 2006). Considering the large number of collections and specimens, extensive database, and distributional analyses (Houghton 2004a, 2007), the Minnesota caddisfly fauna is as well known as any US aquatic insect fauna. We sincerely hope that research on the faunas of other states and taxonomic groups is implemented quickly, so that science-based conservation strategies for this extremely important assemblage of organisms can be implemented on a large scale.

\section{Acknowledgements}

Primary funding for this research came from a US Environmental Protection Agency Science to Achieve Results Fellowship to DCH and substantial support from the Minnesota Nongame Wildlife Tax Checkoff and Minnesota State Park Nature Store Sales through the MNDNR Natural Heritage and Nongame Research Program. Special thanks are due to R. J. Baker, MNDNR, for assistance with the latter funding source. Further support to DCH came from a Doctoral Dissertation Special Grant from the Graduate School, University of Minnesota (UM); several grants from the Dayton and Wilkie Fund, Bell Museum of Natural History, UM; and from grants from the Chiang Travel Fund, Department of Entomology, UM. Further support to RWH came from the UM Insect Collection grants AES0017015 and AES0017017.

We sincerely thank the many workers, from the 1890 s to the 2000s, who have collected Minnesota caddisflies and deposited them into the University of Minnesota Insect Collection, especially R. J. Blahnik, D. G. Denning, D. A. Etnier, W. Elkins, A. A.
Granovsky, J. Huisman, O. Lugger, D. B. MacLean, and M. P. Monson. Furthermore, we thank G. D. Archibald, M. L. Galatowitsch, K. A. Egerman, C. C. Fenendael, P. A. Gillis, K. Ha, A. S. Haughland, T. J. Ling, E. A. Malcolm, N. J. O'Neil, R. C. Stephen, J. M. Zaspel, and J. L. Zeglin for laboratory assistance; and M. Carroll, D. A. Etnier, E. Etnier, K. Ghandi, and R. Suranyi for field assistance. A permit to collect in State Park habitats was provided by E. Quinn, MNDNR, Division of Parks and Recreation. A conversation with W. E. DeWalt stimulated several of our analyses. The valuable comments of R. J. Blahnik and 2 anonymous referees improved earlier versions of the manuscript.

\section{Literature Cited}

Allan, J. D. 1995. Stream ecology: structure and function of running waters. Chapman and Hall, London, UK.

Allan, J. D. 2004. Landscapes and riverscapes: the influence of land use on stream ecosystems. Annual Review of Ecology, Evolution, and Systematics 35:257-284.

Anderson, J. L., J. C. Bell, T. H. Cooper, and D. F. Grigal. 2001. Soils and landscapes of Minnesota. AG-FO-02331. University of Minnesota Extension Service, St. Paul, Minnesota. (Available from: http://www.extension. umn.edu/distribution/cropsystems/DC2331.html)

BAILEY, R. G. 1980. Descriptions of the ecoregions of the United States. U.S. Forest Service Miscellaneous Publications 1391:1-58.

Barbour, M. T., J. Gerritsen, B. D. Snyder, and J. B. Stribling. 1999. Rapid bioassessment protocols for use in streams and rivers: periphyton, benthic macroinvertebrates, and fish. $2^{\text {nd }}$ edition. EPA 841-B-99-002. Office of Water, US Environmental Protection Agency, Washington, DC.

Benke, A. C., and C. E. Cushing. 2004. Rivers of North America. Academic/Elsevier, San Diego, California.

Betten, C. 1934. The caddis flies or Trichoptera of New York State. Bulletin of the New York State Museum 292: 1-576.

Bierley, G. J., T. Cohen, K. Fryirs, and A. Brooks. 1999. PostEuropean changes to the fluvial geomorphology of Bega catchment, Australia: implications for river ecology. Freshwater Biology 41:839-848.

Brinson, M. M., AND A. I. Malvárez. 2002. Temperate freshwater wetlands: types, status, and threats. Environmental Conservation 29:115-133.

Buol, S. W., F. D. Hole, and R. J. McCracken. 1989. Soil genesis and classification. $3^{\text {rd }}$ edition. Iowa State University Press, Ames, Iowa.

Colwell, R. K. 2007. Biota II: The biodiversity database manager. Sinauer Associates, Ltd., Sunderland, Massachusetts.

Delong, M. D., And M. A. Brusven. 1992. Patterns of chlorophyll a in an agricultural non-point source impacted stream. Water Resources Bulletin 28:731-741.

Delong, M. D., And M. A. Brusven. 1993. Storage and decomposition of particulate organic matter along the 
longitudinal gradient of an agriculturally-impacted stream. Hydrobiologia 262:77-88.

Delong, M. D., AND M. A. BRusven. 1998. Macroinvertebrate community structure along the longitudinal gradient of an agriculturally impacted stream. Environmental Management 22:445-457.

DeWalt, D. E., C. Favret, And D. W. Webb. 2005. Just how imperiled are aquatic insects? A case study of stoneflies (Plecoptera) in Illinois. Annals of the Entomological Society of America 98:941-950.

Dodds, W. K., R. E. Huston, A. C. Eichem, M. A. Evans, D. A. Gudder, K. M. Fritz, AND L. J. Gray. 1996. The relationship between flow and light to primary production and producer biomass in a prairie stream. Hydrobiologia 333:151-159.

ElKINS, W. A. 1936. The immature stages of some Minnesota Trichoptera. Annals of the Entomological Society of America 29:656-682.

Flemons, P., R. Guralnick, J. Krieger, A. Ranipeta, and D. NeufELD. 2007. A web-based GIS tool for exploring the world's biodiversity: The Global Biodiversity Information Facility Mapping and Analysis Portal Application (GBIF-MAPA). Ecological Informatics 2:49-60.

Gaubert, P., M. Papes, And A. T. Peterson. 2006. Natural history collections and the conservation of poorly known taxa: ecological niche modeling in central African rainforest genets (Genetta spp.). Biological Conservation 130:106-117.

GaUCH, H. G. 1982. Multivariate analysis in community ecology. Cambridge University Press, New York.

Graham, C. H., S. Ferrier, F. Huettman, C. Moritz, L. Townsend, And A. Peterson. 2004. New developments in museum-based informatics and applications in biodiversity analysis. Trends in Ecology and Evolution 19: 497-503.

Gray, L. J. 1997. Organic matter dynamics in King's Creek, Konza Prairie, Kansas, USA. Pages 50-54 in J. R. Webster and J. L. Meyer (editors). Stream organic matter budgets. Journal of the North American Benthological Society 16.

Gregory, S. V., F. J. Swanson, W. A. McKee, and K. W. Cummins. 1991. An ecosystem perspective of riparian zones. BioScience 41:540-551.

Guralnick, R., And J. Van Cleve. 2005. Strengths and weaknesses of museum and national survey sets for predicting regional species richness: comparative and combined approaches. Diversity and Distributions 11: 349-359.

Harding, J. S., E. F. Benfield, P. V. Bolstad, G. S. Helfman, AND E. B. D. JONES. 1998. Stream biodiversity: the ghost of land use past. Proceedings of the National Academy of Sciences of the United States of America 95:1484314847.

Hawkins, C. P., R. H. Norris, J. Gerritsen, R. N. Hughes, S. K. JACKSON, R. K. Johnson, AND R. J. Stevenson. 2000. Evaluation of the use of landscape classifications for the prediction of freshwater biota: synthesis and recommendations. Iournal of the North American Benthological Societv 19:541-556.
Houghton, D. C. 2003. Evaluation of Minnesota geographic classifications based on caddisfly (Insecta: Trichoptera) data. Great Lakes Entomologist 36:76-92.

Houghton, D. C. 2004a. Minnesota caddisfly biodiversity (Insecta: Trichoptera): delineation and characterization of regions. Environmental Monitoring and Assessment 95:53-182.

Houghton, D. C. 2004b. Utility of caddisflies (Insecta: Trichoptera) as indicators of habitat disturbance in Minnesota. Iournal of Freshwater Ecologv 19:97-108.

Houghton, D. C. 2007. The effects of landscape-level disturbance on the composition of Minnesota caddisflies (Insecta: Trichoptera) trophic functional groups: evidence for ecosystem homogenization. Environmental Monitoring and Assessment 135:253-264.

Houghton, D. C., And R. W. Holzenthal. 2003. Updated conservation status of Minnesota caddisflies. Great Lakes Entomologist 36:35-40.

IUCN (InTERnational Union for Nature AND Natural Resources). 2009. Red list of threatened species. Version 2009.2. International Union for Nature and Natural Resources, Cambridge, UK. (Available from: http:// www.iucnredlist.org/)

Johnson, L. B., D. H. Breneman, And C. Richards. 2003. Macroinvertebrate community structure and function associated with large wood in low gradient streams. River Research and Applications 19:199-218.

KarR, J. K., AND E. Chu. 1999. Restoring life to running waters: better biological monitoring. Island Press, Washington, DC.

Krishtalka, L., AND P. S. Humphrey. 2000. Can natural history museums capture the future? BioScience 50:611-617.

Lebaron, G. S. 2008. The $108^{\text {th }}$ Christmas bird count. American Birds 61:1-9.

Lynse, S. J., K. E. Perez, K. M. Brown, R. L. Minton, and J. D. SIDES. 2008. A review of freshwater gastropod conservation: challenges and opportunities. Iournal of the North American Benthological Society 27:463-470.

Master, L. L., B. A. Stein, L. S. Kutner, and G. A. HAMmerson. 2000. Vanishing assets. Conservation status of U.S. species. Pages 93-118 in B. A. Stein, L. S. Kutner, and J. S. Adams (editors). Precious heritage, the status of biodiversity in the United States. The Nature Conservancy and Association for Biodiversity Information, Oxford Press, Oxford, UK.

Matthews, W. J. 1988. North American prairie streams as systems for ecological study. Iournal of the North American Benthological Society 7:387-409.

McCune, B., And J. B. Grace. 2002. Analysis of ecological communities. MjM Software Design, Gleneden Beach, Oregon.

MNDNR (Minnesota Department of Natural Resources). 2009a. Minnesota Department of Natural Resources lakes, rivers, and wetland facts. Minnesota Department of Natural Resources, St. Paul, Minnesota. (Available from: http:/ / www.dnr.state.mn.us/faq/mnfacts/water. html)

MNDNR (Minnesota Department of Natural Resources). 2009b. Minnesota Department of Natural Resources 
Rare Species Guide, Caddisflies. (Available from: http://www.dnr.state.mn.us/rsg/index.html)

Moulton, S. R. 2004. NABS selects new taxonomic certification program coordinator. Bulletin of the North American Benthological Society 21:449.

Naiman, R. J., C. A. Johnston, and J. C. Kelley. 1988. Alteration of North American streams by beaver. BioScience 38:752-762.

NAtureServe. 2009. NatureServe Explorer: an online encyclopedia of life [web application]. Version 7.1. NatureServe, Arlington, Virginia. (Available from: http:// www.natureserve.org/explorer)

OMERNIK, J. M. 1987. Ecoregions of the conterminous United States. Annals of the Association of American Geologists 77:118-125.

Oswood, M. W., J. B. Reynolds, J. G. Irons, And A. M. Milner. 2000. Distributions of freshwater fishes in ecoregions and hydroregions of Alaska. Iournal of the North American Benthological Society 19:405-418.

Paulsen, S. G., A. Mayio, D. V. Peck, J. L. Stoddard, E. Tarquinio, S. M. Holdsworth, J. Van Sickle, L. L. Yuan, C. P. Hawkins, A. T. Herlihy, P. R. Kaufmann, M. T. Barbour, D. P. Larsen, and A. R. Olsen. 2008. Condition of stream ecosystems in the US: an overview of the first national assessment. Iournal of the North American Benthological Society 27:812-821.

Perkins, S. J. 1994. The shrinking Cedar River: channel changes following flow regulation and bank armoring. Pages 649-658 in R. A. Marston and V. Haffurther (editors). Effects of human-induced changes on hydrologic systems. Annual Summer Symposium, 1994. American Water Resources Association, Vernon, Virginia.

Perez, K. E., And R. L. Minton. 2008. Practical applications for systematics and taxonomy in North American gastropod conservation. Iournal of the North American Benthological Society 27:471-483.

Pringle, C., G. Vellidis, F. Heliotis, D. Bandacu, and S. CRISTOFOR. 1993. Environmental problems for the Danube delta. American Scientist 81:350-361.

QuinN, J. M. 2000. Effects of pastoral development. Pages 209-229 in K. J. Collier and M. J. Winterbourn (editors). New Zealand stream invertebrates: ecology and implications for management. Caxton, Christchurch, New Zealand.

Ricciardi, A. J., AND B. RASMUSSEN. 1999. Extinction rates of North American freshwater fauna. Conservation Biologv 13:1220-1222.

Ross, H. H. 1944. The caddis flies, or Trichoptera, of Illinois. Bulletin of the Illinois Natural History Survey 23:1-326.

Roth, N. E., J. D. Allan, And D. E. ERICKSON. 1996. Landscape influences on stream biotic integrity assessed at multiple spatial scales. Landscape Ecology 11:141-156.

Shapiro, M. H., S. M. Holdsworth, And S. G. Paulsen. 2008. The need to assess the condition of aquatic resources in the US. Iournal of the North American Benthological Society 27:808-811.

Sponseller, R. A., E. F. Benfield, ANd R. M. VAlett. 2001. Relationships between land use, spatial scale, and stream macroinvertebrate communities. Freshwater Biology 46:1409-1424.

StatzNer, B., AND B. Higler. 1985. Questions and comments on the river continuum concept. Canadian Journal of Fisheries and Aquatic Sciences 42:1038-1044.

StRAYER, D. L. 2006. Challenges for freshwater invertebrate conservation. Iournal of the North American Benthological Society 25:271-287.

SuAREZ, A. V., AND N. D. TsuTsur. 2004. The value of museum collections for research and study. BioScience 54:66-74.

Tester, J. R. 1995. Minnesota's natural heritage, an ecological perspective. University of Minnesota Press, Minneapolis, Minnesota.

Thomas, J. A. 2005. Monitoring change in the abundance and distribution of insects using butterflies and other indicator groups. Philosophical Transactions of the Roval Society of London Series B: Biological Sciences 360:339-357.

Thomas, J. A., M. G. Telfer, D. B. Roy, C. D. Preston, J. J. D. Greenwood, J. Asher, R. Fox, R. T. Clarke, and J. H. LAWTON. 2004. Comparative losses of British butterflies, birds, and plants and the global extinction crisis. Science 303:1879-1881.

Turner, R. E., And N. N. Rabalais. 1991. Changes in Mississippi River water quality this century. BioScience 41:140-147.

USFWS (US Fish AND Wildlife SERVice). 2009. Listed FWS/ Joint FWS and NMFS species and populations with recovery plans. US Fish and Wildlife Service, Department of the Interior, Washington, DC. (Available from: http://www.fws.gov/endangered/recovery/index.html\# program/)

USGS (US GeOlogical SuRvey). 2002. Water resources of the United States. US Geological Survey, Reston, Virginia. (Available from: http://water.usgs.gov/)

WANG, L., J. LyONS, AND P. KANEHL. 2001. Impacts of urbanization on stream habitat and fish across multiple spatial scales. Environmental Management 28:255-266.

WANG, L., J. Lyons, P. KANEHL, AND R. Gatti. 1997. Influences of watershed land use on habitat quality and biotic integrity in Wisconsin streams. Fisheries 22(6):6-12.

Wang, L., J. Lyons, P. Rasmussen, and P. Seelbach. 2003. Watershed, reach, and riparian influences on stream fish assemblages in the Northern Lakes and Forest Ecoregion, USA. Canadian Journal of Fisheries and Aquatic Sciences 60:491-505.

WHEELER, Q. D. 2004. Taxonomic triage and the poverty of phylogeny. Philosophical Transactions of the Roval Society of London Series B: Biological Sciences 359: 571-583.

Wiggins, G. B. 2008. Trichoptera families. Pages 439-480 in R. W. Merritt, K. W. Cummins, and M. B. Berg (editors). An introduction to the aquatic insects of North America. $4^{\text {th }}$ edition. Kendall/Hunt, Dubuque, Iowa.

Wilcove, D. S., AND L. L. Master. 2005. How many endangered species are there in the United States? Frontiers in Ecology and the Environment 3:414-420.

Wiley, M. J., L. L. Osborne, and R. W. Larimore. 1990. Longitudinal structure of an agricultural prairie river 
system and its relationship to current stream ecosystem theory. Canadian Journal of Fisheries and Aquatic Sciences 47:373-384.

Williams, P., M. Whitfield, J. Biggs, S. Bray, G. Fox, P. Nicolet, AND D. SEAR. 2003. Comparative biodiversity of rivers, streams, ditches, and ponds in an agricultural landscape in southern England. Biological Conservation 115:329-341.

WINKLER, K. 2004. Natural history museums in a postbiodiversity era. BioScience 54:455-459.

Wishart, M. J., AND B. R. DAvies. 2003. Beyond catchment considerations in conservation of lotic biodiversity. Aquatic Conservation 13:429-437.
Zimmerman, J. K., B. VondraceK, AND J. V. Westra. 2003. Agricultural land use effects on sediment loading and fish assemblages in two Minnesota (USA) watersheds. Environmental Management 32:93-105.

ZWEIG, L. D., AND C. F. RABENI. 2001. Biomonitoring effects of deposited sediment in streams. Iournal of the North American Benthological Society 20:643-657.

Received: 5 March 2009 Accepted: 12 January 2010 